\title{
REVIEW \\ Incretin hormones and the satiation signal
}

\author{
JJ Holst
}

Recent research has indicated that appetite-regulating hormones from the gut may have therapeutic potential. The incretin hormone, glucagon-like peptide-1 (GLP-1), appears to be involved in both peripheral and central pathways mediating satiation. Several studies have also indicated that GLP-1 levels and responses to meals may be altered in obese subjects. Clinical trial results have shown further that two GLP-1 receptor agonists (GLP-1 RAs), exenatide and liraglutide, which are approved for the treatment of hyperglycemia in patients with type 2 diabetes, also produce weight loss in overweight subjects without diabetes. Thus, GLP-1 RAs may provide a new option for pharmacological treatment of obesity.

International Journal of Obesity (2013) 37, 1161-1168; doi:10.1038/ijo.2012.208; published online 8 January 2013

Keywords: exenatide; glucagon-like peptide-1; incretin; liraglutide

\section{INTRODUCTION}

The incretin hormones are gut hormones that amplify nutrientinduced insulin secretion in response to meal intake. Glucagonlike peptide-1 (GLP-1) and glucose-dependent insulinotropic polypeptide (GIP) are the two most important hormones and both are thought to contribute equally to the effect. ${ }^{1}$ GLP-1 is secreted from endocrine cells in the epithelium of the small intestine thatexpress the proglucagon gene, the so-called $L$ cells. Unlike in the pancreas, the gene product, (pre)proglucagon, is processed here to release the two glucagon-like hormones, GLP-1 and GLP- $2{ }^{2}$ whereas the glucagon sequence is buried in an $\mathrm{N}$-terminal fragment of proglucagon called glicentin. ${ }^{3}$ GLP-1 binds to a single GLP-1 receptor ${ }^{4}$ and possesses several physiological effects that contribute to the regulation of glucose (Figure 1). ${ }^{4-7}$ GIP is secreted from $\mathrm{K}$ cells in the proximal small bowel and binds to GIP receptors expressed by pancreatic islet $\beta$ cells, as well as to receptors in adipose tissue and the brain. ${ }^{5} \mathrm{~A}$ large body of data indicate that GLP-1 has an important role in satiation signaling, but this does not appear to be the case for GIP. ${ }^{8}$ As a result, the remainder of this review focuses on GLP-1. On the other hand, GIP may be involved the development of obesity, as mice with GIP receptor deletions are resistant to diet-induced obesity. ${ }^{9}$ This is thought to reflect an action of GIP on the adipose tissue promoting fat storage, although this is controversial..$^{9-11}$

\section{GLP-1 AND REGULATION OF APPETITE}

As outlined in Figure 1, GLP-1 has numerous targets that may also be important in the regulation of food intake. The widespread distribution of GLP-1 receptors in the brain ${ }^{12}$ suggested actions of GLP-1 on brain centers, and in early studies, Schick et al. ${ }^{13}$ demonstrated inhibition of food intake after intracerebroventricular (ICV) as well as direct hypothalamic administration of GLP-1 in rats. This was followed up by extensive studies by Turton et al. $^{14}$ and Tang-Christensen et al. ${ }^{15}$ demonstrating powerful inhibition of food intake after ICV administration of GLP-1, an effect that could be blocked by the specific receptor antagonists exendin 9-39, which also enhanced spontaneous as well as neuropeptide Y-stimulated food intake. These experiments established central GLP-1 as a physiological regulator of food intake maintaining an inhibitory tonus. These cerebral actions of GLP-1 are unlikely to reflect the actions of peripherally produced GLP-1 but are rather targets for GLP-1 produced in and released from projections of neurons of the nucleus of the solitary tract, which express the proglucagon gene and have a processing pattern like the $L$ cells of the gut. ${ }^{16-19}$ Cells positive for GLP-1 mRNA are widely expressed in the human brain in areas, including the frontal, parietal, temporal and occipital cortices; the basal ganglia; ${ }^{20}$ and the hypothalamus. ${ }^{21}$ Radioligand-binding studies have shown high densities of GLP-1 receptors in the lateral septum, the subfornical organ, the thalamus, the hypothalamus, the interpenduncular nucleus, the posterodorsal tegmental nucleus, the area postrema (AP), the inferior olive and the nucleus tractus solitarius (NTS). ${ }^{12}$ Recent studies provide a direct demonstration of actions of central GLP-1 and show projections from GLP-1-containing neurons in the NTS to the nucleus accumbens core and of satiation induced by injections of GLP-1 into this region of the accumbens. ${ }^{22,23}$ Furthermore, GLP-1 receptors in this region and in the ventral tegmental area appear to be responsible for an inhibitory effect of GLP-1 on the rewarding value of food in rats. ${ }^{24}$ GLP-1 receptors are also present in the floor of the fourth ventricle, notably the subfornical organ and the AP, areas not fully blocked from the peripheral circulation by the blood-brain barrier. These areas are accessible to circulating peripheral GLP-1 and thus may permit direct effects of this peptide in the central nervous system (CNS). ${ }^{12,25,26}$ It has been also been claimed that GLP-1 may pass the blood-brain barrier even outside these leaks, ${ }^{26}$ but it is currently unknown to what extent this route may be involved in signaling from the gut to the brain.

The central GLP-1 system has been studied by several groups (reviewed in Vrang and Larsen ${ }^{27}$ ), and there is little doubt that it represents an important central appetite regulating mechanism, although its physiological role is currently uncertain. In rats, it may be activated by peripheral signals, such as distension of the stomach that activate the GLP-1-expressing neurons of the NTS, ${ }^{28}$ and it has also been associated with enteroceptive stress; ${ }^{29,30}$ however, its relation to food intake is unclear. ${ }^{29}$ Inconsistent 


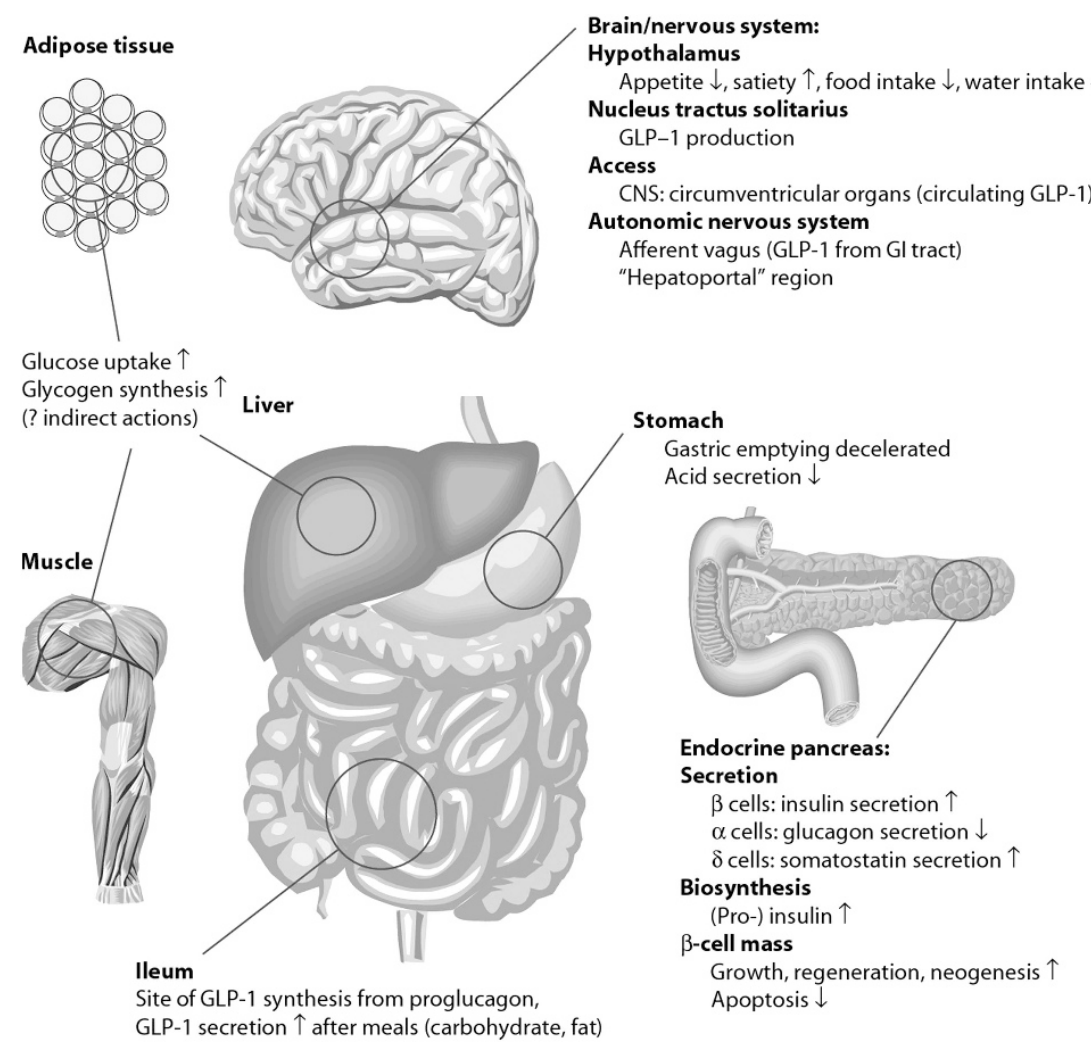

Figure 1. Physiological effects of GLP-1. Reprinted with permission from Drucker and Nauck, $2006 .{ }^{5}$

findings in other species (mice) render the generality of these findings unclear. ${ }^{31}$ On the other hand, knock down of the GLP-1producing neurons as well as chronic administration of the GLP-1 receptor antagonist (GLP-1 RA), exendin 9-39, was associated with hyperphagia and increased fat accumulation after high fat feeding in rats. ${ }^{32}$

The relationship between the peripheral and the central GLP-1 system is also unclear. Williams reported that while central blockade of the GLP-1 system with ICV administration of exendin 9-39 blocked the actions of central but not peripheral GLP-1, peripheral (intraperitoneal) exendin 9-39 blocked the appetite-suppressing actions of peripheral, but not central GLP-1, indicating that the two systems do not depend on each other for activity. However, other studies did report blocking effect of central exendin 9-39 on the effects of peripheral GLP-1 RAs. ${ }^{33}$ At any rate, the GLP-1 neurons do not express GLP-1 receptors (but may be depolarized by leptin), ${ }^{34}$ but it is of interest that other neurons in the dorsal motor nucleus of the vagus with efferent projections to the stomach do increase their firing rates in response to GLP-1. ${ }^{35}$

GLP-1 secreted from the gut is also likely to be a physiological regulator of appetite and food intake. The first experiments demonstrating effects of peripheral GLP-1 in humans were published by Flint et al. $^{36}$ in 1998. These investigators used visual analog scores for appetite registration and also studied the effect on ad libitum food intake. The doses used were highly physiological. Subsequent studies defined the dose-response relationships and demonstrated that an effect was also apparent in obese subjects and in obese patients with type 2 diabetes (T2DM). ${ }^{37,38}$ In a meta-analysis of available data, Verdich et al. ${ }^{39}$ demonstrated that the effect on food intake was linearly related to the dose of GLP-1 infused. Subsequent studies with stable GLP-1 RAs leave no doubt about the effectiveness with respect to inhibition of food intake, ${ }^{40}$ see below.
The question then arises whether peripheral GLP-1 is a physiological regulator of food intake. Again, the antagonist exendin 9-39 has helped answer the question. Thus, when given intraperitoneally, the antagonist significantly augmented food intake in rats in the light period and the late dark period (periods of limited food intake); conversely, little effect was noted at the onset of the dark period, where food intake is maximal, suggesting that during this period the inhibitory systems are shut down and therefore there is nothing to antagonize. ${ }^{41}$ In another study, a new, long-acting GLP-1 RA (an acylated GLP-1/exendin 9-39 hybrid) not only inhibited food intake but also lowered body weight. ${ }^{42}$ Similar studies have not yet been carried out in humans, but studies of weight loss after gastric bypass operations showed a correlation with GLP-1 responses. ${ }^{43}$ These observations also support the hypothesis that peripheral GLP-1 is a physiological regulator of appetite/food intake.

\section{IS GLP-1 INVOLVED IN THE PATHOGENESIS OF OBESITY?}

In accordance with the proposed actions for GLP-1, levels of this peptide increase in response to nutrient intake ${ }^{6}$ and the magnitude of the secretory response depends on the amount of nutrient consumed. ${ }^{6,44-47}$ However, it has been clearly shown that circulating levels of GLP-1 are reduced in obese patients. Results from a study carried out more than 25 years ago indicated that the normal enteroglucagon (=glicentin + oxyntomodulin, cosecreted with GLP-1 from the L cells) responses to meals were decreased by about $75 \%$ in obese subjects. ${ }^{48}$ Similar findings were made in more recent studies. ${ }^{49-55}$ By contrast, GIP responses are often increased rather than decreased. ${ }^{47}$ The reason for the differential effects of meal ingestion on GLP-1 and GIP levels is not known. GLP-1 responses to oral stimulation have been negatively correlated to body mass index (BMI), ${ }^{6}$ and weight loss was associated with increasing GLP-1 responses to meal ingestion. ${ }^{49}$ 
It has been suggested that the decrease may be related to the insulin resistance that accompanies weight gain and/or reduced $\mathrm{L}$-cell responsiveness to carbohydrates secondary to increased levels of circulating fatty acids. ${ }^{6,56}$ The major rise in plasma GLP-1 is often observed following completion of a meal, later than the presumed effect on eating occurs, ${ }^{57}$ which is in agreement with the notion that entry of digested nutrients into the $L$ cells provide the stimulus for secretion. ${ }^{58}$ However, GLP-1 levels do show an early increase $(10 \mathrm{~min})$ after meal ingestion in humans, ${ }^{47,59}$ presumably because of secretion from $L$ cells situated in the upper jejunum. ${ }^{6}$

Interestingly, a recent study showed that both moderate and intense exercise increased GLP-1 levels and decreased hunger and that elevations in GLP-1 were inversely correlated with energy intake post-exercise. ${ }^{60}$ Overall, individuals who have lost weight as a function of changes in diet or exercise have increases in GLP-1, ${ }^{6}$ which may contribute to the weight reductions/maintenance observed with these interventions.

\section{GLP-1 in bariatric surgery}

Conversely, results from several studies have indicated that elevation of GLP-1 may be involved in the weight loss observed in patients who undergo bariatric surgery. ${ }^{61-64}$ GLP-1 levels increase dramatically in response to meal ingestion ${ }^{65}$ and, as mentioned above, levels correlate with decreases in weight and appetite. ${ }^{62}$ The mechanisms underlying the increase in GLP-1 levels associated with bypass surgery are not fully understood. Results from one recent study indicated that patients who have undergone bypass surgery have an $11.6 \%$ decrease in dipeptidyl peptidase-4 (DPP-4) activity, ${ }^{66}$ and as that enzyme inactivates GLP1 , this change could contribute to increased peptide levels. It has also been shown that insulin resistance reduces GLP-1 secretion in response to an oral glucose challenge, ${ }^{67}$ and it has been shown that bypass surgery significantly decreases insulin resistance, 68 but again these mechanisms would only be expected to explain a very small part of the increase. Rather, it is the surgical rerouting of ingested nutrients to the distal small intestine with a high density of $L$ cells that increases GLP-1 secretion (the hindgut hypothesis). ${ }^{69,70}$ This was demonstrated clearly in a case report where a meal was given to a patient on two consecutive days 5 weeks after gastric bypass, one via the oral route (by-passing the stomach and upper small intestine) and the other via a gastrostomy catheter. ${ }^{71}$ The oral meal resulted in the expected exaggerated post-bypass GLP-1 response, whereas the response to the gastric meal resembled preoperative responses. The exaggerated GLP-1 response after bypass in patients with T2DM has been demonstrated to be responsible for at least part of the improved beta-cell function and therefore resolution of diabetes using the receptor antagonists, $^{72}$ but so far similar studies regarding appetite/food intake have not been reported.

\section{MECHANISMS OF GLP-1 INHIBITION OF SATIETY/FOOD INTAKE}

How does peripheral GLP-1 interfere with the regulation of satiety and food intake? As mentioned, plasma concentrations rise after meal intake, but it turns out that newly released GLP-1 is degraded and inactivated (at least with regard to its insulin-releasing effects) almost instantaneously after its release. Newly released GLP-1 diffuses across the basal lamina and into the lamina propria, enters capillaries where the enzyme, DPP-4, is located in the luminal membranes of the endothelial cells and degrades the peptide, so that only $1 / 3$ to $1 / 4$ of the intact peptide is left once the products reach the portal vein. ${ }^{73}$ In the liver, more DPP-4 degrades $50 \%$ of what is left, ${ }^{74}$ leaving very little intact GLP-1 for circulation; ${ }^{73}$ a soluble DPP-4 may degrade what is left. ${ }^{75}$ The plasma concentration of intact GLP-1 does rise, but the rise represents only a small percentage of what was originally secreted. ${ }^{76}$ In view of the dose-response relationship, ${ }^{39}$ it seems impossible that these minor increases could be responsible for any inhibition of food intake. A similar elevation in the concentration of intact GLP-1 may be obtained by inhibitors of DPP-4; ${ }^{77}$ however, inhibitor treatment has no effect on body weight. ${ }^{78}$ Instead, GLP-1 released by L cells in the gut may reduce food intake through an effect on peripheral GLP-1 receptors located on vagal sensory afferents in the gut or perhaps in the hepatoportal region of the liver. ${ }^{73,79-81}$ These nerve fibers have their cell bodies in the nodose ganglion where abundant GLP-1 receptor mRNA has been demonstrated. ${ }^{82,83}$ The neurons subsequently project to the NTS. Indeed, neurons of the NTS have been shown to be activated (c-fos expression) in response to peripheral GLP-1 administration. ${ }^{84}$ In turn, the activated NTS neurons may not only directly influence the vagal motor nuclei in the dorsal part of the brain stem ${ }^{85}$ but also project to hypothalamic nuclei, including the arcuate (presumably mainly involved in glucose regulation ${ }^{86}$ ), the paraventricular nucleus (PVN) of the hypothalamus and the amygdala. ${ }^{16,84}$ Note that the NTS neurons are probably not the GLP-1-expressing neurons. Efferent pathways reaching and regulating the function of gastrointestinal organs and pancreas may emerge from the hypothalamus and the dorsal motor nuclei. ${ }^{87}$

This concept is supported by results from further studies in animals showing that either total subdiaphragmatic vagotomy ${ }^{88}$ or selective vagal deafferentation ${ }^{89,90}$ significantly decreased the food intake reduction observed with peripheral administration of GLP-1. A similar neural pathway was also demonstrated to apply to GLP-1-induced inhibition of gastric emptying, antral motility and gastric-end pancreatic secretion. ${ }^{91,92}$ Thus, in humans, gastric acid secretion, stimulated by a purely vagal stimulus, namely shame feeding, is completely abolished by high physiological doses of GLP-1, ${ }^{93}$ and the inhibitory effect is lost after truncal vagotomy. $^{94}$

However, there is also evidence that GLP-1 may act directly in the brain as a satiation signal. ${ }^{95,96}$ As noted previously, GLP-1 may have direct effects in the CNS because it can reach the brainstem via the subfornical organ and AP, which lack a typical blood-brain barrier. ${ }^{97} \mathrm{~A}$ direct central effect of GLP-1 is supported by results from a study which showed that only the effect of intraperitoneal, but not intravenous (intraportal), GLP-1 on eating required vagal afferent signaling. ${ }^{89}$ Thus, although supporting the assumption that the effects of endogenous GLP-1 released by the intestinal L cells may involve transmission via vagal afferents (which were supposed to be activated in the gut wall by intraperitoneal GLP-1 diffusing across the gut wall from the peritoneal cavity to engage the vagal receptors), additional pathways, engaged by IV GLP-1, must also exist and may include interaction with the brain sites accessible from the bloodstream. ${ }^{89}$ Indeed, in a recent study involving intraportal administration of GLP-1 (which inhibited food intake), neurons were activated (c-fos expression) in both the nucleus of the solitary tract, the AP and the central nucleus of the amygdala. ${ }^{98}$ Furthermore, it has recently been demonstrated that the hepatic branch of the vagus nerve is not essential for the reduction in food intake induced by intraportal administration of GLP-1. ${ }^{90}$ On the other hand, the AP pathway does not appear to be solely responsible for the GLP-1-induced satiation as this was unaffected after deletion of the AP as well as the subfornical organ. ${ }^{98}$ In recent studies in humans, it was demonstrated that the acute inhibitory effect of peripheral GLP-1 on energy intake after a meal is lost in subjects with a truncal vagotomy. ${ }^{99}$

Figure 2 illustrates a proposed pathway for GLP-1 signaling in relation to satiation and glucose metabolism. ${ }^{6,79,100}$ In response to the presence of nutrients in the gastrointestinal tract, intestinal $L$ cells release GLP-1, which binds to receptors on vagal afferents innervating the gut. The resulting vagal activation sends a signal to neurons of the NTS. GLP-1 also reaches the pancreas via the circulation to act directly on $\beta$ cells, although this contribution 


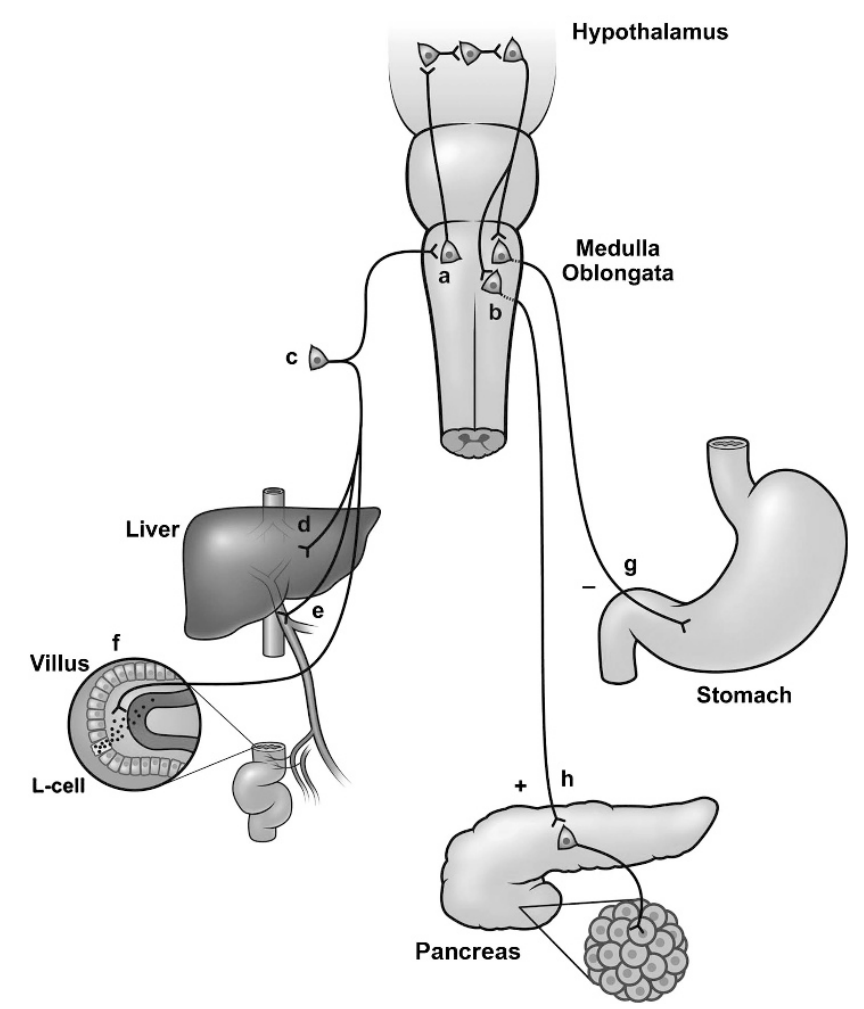

Figure 2. The neural pathway for the actions of GLP-1. GLP-1 secretion is stimulated by nutrients in (a) the gut lumen, and newly released GLP-1 diffuses across the basal lamina into the lamina propria. On its way to the capillary, however, it may bind to and activate (f) sensory afferent neurons originating in the (c) nodose ganglion, which may, in turn, activate neurons of the NTS (a). The same pathway may be activated by sensory neurons in (e) the hepatoportal region or in (d) the liver tissue. Ascending fibers from the NTS may generate reflexes in the hypothalamus, and descending impulses (from neurons in the PVN?) may activate (b) vagal motor neurons, that send (h) stimulatory or (g) inhibitory impulses to the pancreas and the gastrointestinal tract. Interactions between ascending sensory nerve fibers and vagal motor neurons may also take place at the level of the brain stem. Reprinted with permission from Holst, 2007.6

may often be small because of the inactivation of GLP-1 caused by the enzyme DPP-4, which takes place in the gut before the hormone reaches the systemic circulation, but after it has had a chance to interact with the sensory afferents. ${ }^{80}$ Food intake also promotes the release of other gastrointestinal hormones (for example, cholecystokinin) that could increase the firing of GLP-1 neurons in the NTS. ${ }^{101}$ Afferent neural pathways are likely to participate as well. Stimulated GLP-1-expressing NTS neurons that signal satiation to brain areas may be involved in modulating food intake (mainly via the PVN) and glucose metabolism (mainly via the ARC) and thus may contribute to appetite suppression, although this is controversial. ${ }^{27}$ Regardless of the pathways involved, it is important to note that GLP-1 reduces appetite by affecting the function of regulating centers of the brain, ${ }^{102}$ rather than primarily affecting gastrointestinal motor activity (gastric emptying) or by causing nausea. Studies in humans also support the central effects of GLP-1. Thus, peak postprandial increases in plasma GLP-1 concentrations were found to correlate with increases in regional cerebral blood flow in the left dorsolateral prefrontal cortex (including the left middle and inferior frontal gyri). Both of these areas have been previously implicated to be involved in the regulation of food intake in animal and human studies. $^{95}$ GLP-1 also has interactions with ghrelin that may contribute to weight loss. Ghrelin is an orexigenic peptide hormone. It is released into the systemic circulation mainly by the X/A-like cells in stomach mucosa. ${ }^{103}$ Results from recent studies have demonstrated that GLP-1 (both central, ICV and peripheral) inhibits ghrelin-stimulated neuronal activity in the hypothalamus as well as its effects on food intake. ${ }^{104,105}$ This may contribute to the effects of GLP-1 on meal consumption.

\section{WEIGHT LOSS WITH GLP-1 RAs}

Currently available GLP-1 RAs include liraglutide and exenatide. Liraglutide is a human GLP-1 RA analog with $97 \%$ homology to human GLP-1. ${ }^{106,107}$ Liraglutide has a 13-h half-life, which makes it suitable for once-daily administration. ${ }^{108}$ Exenatide is a full GLP-1 RA isolated from the saliva of a lizard, the Gila monster, with a 53\% homology to native GLP-1 and a 2.5-h half-life after subcutaneous administration. ${ }^{106,109}$ This molecule is naturally resistant to DPP-4 and is now also available in an extended-release form allowing once-weekly administration. ${ }^{109}$ Results from multiple clinical trials have demonstrated that exenatide treatment results in weight loss in patients with T2DM. ${ }^{110,111}$ Clinical trial results have also shown that liraglutide results in weight loss whether used as monotherapy or as part of combination treatment in patients with T2DM. ${ }^{110,112-114}$ Meta-analysis of results for clinical trials with exenatide and liraglutide in patients with diabetes indicated that reductions in BMI versus placebo were -0.62 and $-0.47 \mathrm{~kg} \mathrm{~m}^{-2}$ respectively. ${ }^{110}$ A separate systematic review of results for exenatide indicated weight losses of $3-6 \mathrm{~kg}$ over 52 weeks of treatment. ${ }^{111}$ Analysis of results of a substudy of the LEAD-2 (Liraglutide Effect and Action in Diabetes) trial indicated weight loss of $0.9,2.0$ and $3.2 \mathrm{~kg}$ among patients treated with $0.6,1.2$ and $1.8 \mathrm{mg}$ liraglutide over 26 weeks of treatment. ${ }^{112,115}$ Direct comparison of results for exenatide and liraglutide in the LEAD6 trial indicated weight losses of $3.24 \mathrm{~kg}$ for liraglutide and $2.87 \mathrm{~kg}$ with exenatide over 26 weeks of treatment. ${ }^{16}$ Treatment with liraglutide $\left(0.3-0.9 \mathrm{mg} \mathrm{day}^{-1}\right)$ for 20 days significantly reduced waist circumference, waist/hip ratio and estimated visceral fat area in a small cohort of 20 Japanese patients with T2DM. ${ }^{117}$ The consistent weight reductions observed with liraglutide and exenatide in patients with T2DM have prompted evaluation of these agents in nondiabetic patients who require pharmacotherapy for weight loss (see below). ${ }^{118-120}$

Mechanisms underlying weight loss in patients receiving GLP-1 RAs for treatment of diabetes may include increased satiation signaling involving the pathways described previously. Studies in healthy volunteers have demonstrated that exenatide increases satiation and reduces caloric intake by $209.3 \mathrm{kcal}$ versus placebo when administered $60 \mathrm{~min}$ before a standardized meal. ${ }^{121}$ Liraglutide has been shown to decrease energy intake in association with earlier satiation. ${ }^{122}$

GLP-1 RAs also slow gastric emptying and decrease gut motility (whereas GIP does not possess such actions ${ }^{8}$ ). The decreased gastric emptying observed with GLP-1 RAs may contribute to weight loss as it is known that gastric distension is associated with decreased food intake (and activation of GLP-1-producing neurons of the nucleus of the solitary tact). ${ }^{28}$ Exenatide slows gastric emptying of both solid and liquid meal components, and this is associated with decreased postprandial glucose levels. ${ }^{123}$ Clinical studies of liraglutide also indicate that it delays gastric emptying, ${ }^{124}$ although its effect during chronic treatment is much smaller. ${ }^{125}$ It has been suggested that delayed gastric emptying resulting from administration of a GLP-1 RA is due to inhibition of vagal afferent fibers. ${ }^{92,126}$ However, it is clear that GLP-1 and GLP-1 RAs inhibit appetite independently of their effects on gastric emptying as the effect is observed also in fasting individuals (with empty stomachs) ${ }^{37}$ and chronic treatment with liraglutide and exenatide brings about similar weight losses, although the effect of liraglutide on gastric emptying is very small compared with that 


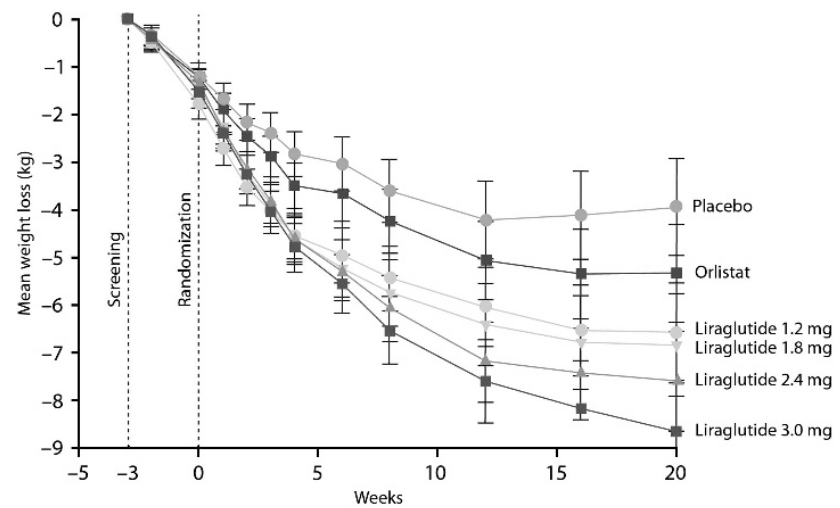

Figure 3. Mean changes in body weight with liraglutide, orlistat or placebo. Reprinted with permission from Astrup, 2009. ${ }^{118}$

of exenatide. It should also be noted that results from several studies with liraglutide and exenatide have indicated that weight loss associated with these agents is not as a result of nausea observed in some patients treated with GLP-1 RAs. ${ }^{15,127-131}$ It has also been shown that weight loss with GLP-1 RAs is greatest in patients with the highest baseline BMI. ${ }^{132}$

Recent clinical trials in obese patients without diabetes have indicated that GLP-1 RA treatment also decreases body weight in this group. In one recent study, obese subjects $(N=152$; mean $\mathrm{BMI}=39.6 \mathrm{~kg} \mathrm{~m}^{-2} ; 25 \%$ with impaired glucose tolerance or impaired fasting glucose) were randomized to receive exenatide or placebo along with lifestyle intervention for 24 weeks. Exenatide-treated subjects lost $5.1 \mathrm{~kg}$ from baseline versus $1.6 \mathrm{~kg}$ with placebo. ${ }^{120}$ In another recent double-blind, placebocontrolled, 20-week trial, 564 individuals (18-65 years of age, $\mathrm{BMI}=30-40 \mathrm{~kg} \mathrm{~m}^{-2}$ ) were randomized to liraglutide doses (1.2 mg, $1.8 \mathrm{mg}, 2.4 \mathrm{mg}$, or $3.0 \mathrm{mg}, n=90-95$ per group), placebo $(n=98)$ or orlistat $(120 \mathrm{mg}, n=95)$. All subjects had a $2093 \mathrm{~kJ}$ (500 kcal)-per-day, energy-deficit diet and increased their physical activity as measured by a pedometer throughout the trial. Mean weight losses with liraglutide 1.2, 1.8, 2.4 and $3.0 \mathrm{mg}$ were 4.8, 5.5, 6.3 and $7.2 \mathrm{~kg}$, respectively, compared with $2.8 \mathrm{~kg}$ with placebo and $4.1 \mathrm{~kg}$ with orlistat (Figure 3). ${ }^{118}$ Recently reported results indicate that the efficacy of liraglutide for weight loss is sustained for at least 2 years. ${ }^{118,129}$ Importantly, in obese individuals with impaired glucose tolerance (about a third of the subjects), this was normalized in most during therapy, suggesting that GLP-1 RAs may actually prevent development of T2DM in individuals at risk.

\section{CONCLUSIONS}

Results from studies in both experimental animals and humans have indicated that GLP-1 has a key role in satiation signaling. In the periphery, satiation-inducing effects of GLP-1 are most probably mediated by vagal afferents originating in the intestine in combination with other mechanism that may involve circumventricular organs, and peripheral GLP-1 appears to activate CNS nuclei that are involved in satiation, including the PVN, the central nucleus of the amygdala and possibly the nucleus accumbens. Intrinsic to the CNS, a GLP-1 pathway arising in the NTS is also involved in satiation. ICV administration of GLP-1 receptors in the CNS reduces food intake, and GLP-1 RAs induce hyperphagia. Circulating levels of GLP-1, including responses to meals, are decreased in obese individuals. Weight loss associated with diet and exercise or bariatric surgery is associated with increased GLP1 levels, and it has been suggested that elevated satiation signaling mediated by GLP-1 may contribute to weight loss in both the settings.
Pharmacological options for the treatment of obesity are limited, and most patients are unable to achieve sustained reductions in weight with diet and exercise alone. GLP-1 has multiple peripheral and CNS effects that contribute to satiation and decreased caloric intake. Indeed, part of the weight losspromoting effect of gastric bypass operations seems to involve exaggerated postprandial secretion of GLP-1. Furthermore, the GLP-1 RAs, exenatide and liraglutide, have been consistently shown to decrease body weight when used for the treatment of hyperglycemia in patients with T2DM. Clinical trial results from obese patients without diabetes have shown that both exenatide and liraglutide can produce significant reductions in body weight in such individuals. Thus, it is reasonable to suggest that these decreases may be due, at least in part, to increased satiation signaling associated with these GLP-1 RAs. This suggests that the GLP-1 RAs may be of use in the treatment of obesity, perhaps particularly with a view to prevent development of diabetes in obese subjects with impaired glucose tolerance.

\section{CONFLICT OF INTEREST}

$\mathrm{J} \mathrm{H}$ wrote the manuscript, with editorial assistance from the medical writer, reviewed and revised all outlines and drafts and approved the final version that was submitted. $\mathrm{JJH}$ has received payment as a consultant and speaker from Novo Nordisk Inc., for development of educational presentations from Forward Pharma and for travel, accommodations or meeting expenses from MSD.

\section{ACKNOWLEDGEMENTS}

I thank Robert W. Rhoades, PhD, of MedVal Scientific Information Services, LLC, for providing editorial assistance. This manuscript was prepared according to the International Society for Medical Publication Professionals' Good Publication Practice for Communicating Company-Sponsored Medical Research: the GPP2 Guidelines. Funding to support the preparation of this manuscript was provided by Novo Nordisk Inc.

\section{REFERENCES}

1 Vilsboll T, Krarup T, Madsbad S, Holst JJ. Both GLP-1 and GIP are insulinotropic at basal and postprandial glucose levels and contribute nearly equally to the incretin effect of a meal in healthy subjects. Regul Pept 2003; 114: 115-121.

2 Holst JJ, Deacon CF, Vilsboll T, Krarup T, Madsbad S. Glucagon-like peptide-1, glucose homeostasis and diabetes. Trends Mol Med 2008; 14: 161-168.

3 Holst JJ. The physiology of glucagon-like peptide 1. Physiol Rev 2007; 87: 1409-1439.

4 Drucker DJ. The biology of incretin hormones. Cell Metab 2006; 3: 153-165.

5 Drucker DJ, Nauck MA. The incretin system: glucagon-like peptide-1 receptor agonists and dipeptidyl peptidase-4 inhibitors in type 2 diabetes. Lancet 2006; 368: 1696-1705.

6 Holst JJ. The physiology of glucagon-like peptide 1. Physiol Rev 2007; 87: 1409-1439.

7 Stonehouse A, Okerson T, Kendall D, Maggs D. Emerging incretin based therapies for type 2 diabetes: incretin mimetics and DPP-4 inhibitors. Cur Diabetes Rev 2008; 4: 101-109.

8 Edholm T, Degerblad M, Gryback P, Hilsted L, Holst JJ, Jacobsson H et al. Differential incretin effects of GIP and GLP-1 on gastric emptying, appetite, and insulin-glucose homeostasis. Neurogastroenterol Motil 2010; 22: 1191-1201.

9 Miyawaki K, Yamada Y, Ban N, Ihara Y, Tsukiyama K, Zhou H et al. Inhibition of gastric inhibitory polypeptide signaling prevents obesity. Nat Med 2002; 8: 738-742.

10 Ugleholdt R, Pedersen J, Bassi MR, Fuchtbauer EM, Jorgensen SM, Kissow $\mathrm{HL}$ et al. Transgenic rescue of adipocyte glucose-dependent insulinotropic polypeptide receptor expression restores high fat diet-induced body weight gain. J Biol Chem 2011; 286: 44632-44645.

11 Asmar M, Tangaa W, Madsbad S, Hare K, Astrup A, Flint A et al. On the role of glucose-dependent insulintropic polypeptide in postprandial metabolism in humans. Am J Physiol Endocrinol Metab 2010; 298: E614-E621.

12 Goke R, Larsen PJ, Mikkelsen JD, Sheikh SP. Distribution of GLP-1 binding sites in the rat brain: evidence that exendin- 4 is a ligand of brain GLP-1 binding sites. Eur J Neurosci 1995; 7: 2294-2300.

13 Schick RR, vorm Walde T, Zimmermann JP, Schusdziarra V, Classen M. Glucagonlike peptide $1-a$ novel brain peptide involved in feeding regulation. 
In: Ditschuneit H, Gries FA, Hauner H, Schusdziarra V, Wechsler JG (eds.) Obesity in Europe 1993. John Libbey \& Co.Ltd, 1994, pp 363-367.

14 Turton MD, O'Shea D, Gunn I, Beak SA, Edwards CM, Meeran K et al. A role for glucagon-like peptide-1 in the central regulation of feeding [see comments]. Nature 1996; 379: 69-72.

15 Tang-Christensen M, Larsen PJ, Goke R, Fink-Jensen A, Jessop DS, Moller M et al. Central administration of GLP-1-(7-36) amide inhibits food and water intake in rats. Am J Physiol 1996; 271(Pt 2): R848-R856.

16 Larsen PJ, Tang-Christensen M, Holst JJ, Orskov C. Distribution of glucagon-like peptide-1 and other preproglucagon- derived peptides in the rat hypothalamus and brainstem. Neuroscience 1997; 77: 257-270.

17 Burcelin R, Cani PD, Knauf C. Glucagon-like peptide-1 and energy homeostasis. J Nutr 2007; 137(11 Suppl): 2534S-2538S.

18 Shimizu I, Hirota M, Ohboshi C, Shima K. Identification and localization of glucagon-like peptide-1 and its receptor in rat brain. Endocrinology 1987; 121: 1076-1082.

19 Ranganath LR. The entero-insular axis: implications for human metabolism. Clin Chem Lab Med 2008; 46: 43-56.

20 Mora F, Exposito I, Sanz B, Blazquez E. Selective release of glutamine and glutamic acid produced by perfusion of GLP-1 (7-36) amide in the basal ganglia of the conscious rat. Brain Res Bull 1992; 29: 359-361.

21 Alvarez E, Martinez MD, Roncero I, Chowen JA, Garcia-Cuartero B, Gispert JD et al. The expression of GLP-1 receptor mRNA and protein allows the effect of GLP-1 on glucose metabolism in the human hypothalamus and brainstem. J Neurochem 2005; 92: 798-806.

22 Alhadeff AL, Rupprecht LE, Hayes MR. GLP-1 neurons in the nucleus of the solitary tract project directly to the ventral tegmental area and nucleus accumbens to cntrol for food intake. Endocrinology 2011; 153: 647-658.

23 Dossat AM, Lilly N, Kay K, Williams DL. Glucagon-like peptide 1 receptors in nucleus accumbens affect food intake. J Neurosci 2011; 31: 14453-14457.

24 Dickson SL, Shirazi RH, Hansson C, Bergquist F, Nissbrandt H, Skibicka KP. The glucagon-like peptide 1 (GLP-1) analogue, exendin-4, decreases the rewarding value of food: a new role for mesolimbic GLP-1 receptors. J Neurosci 2012; 32 4812-4820.

25 Chaudhri O, Small C, Bloom S. Gastrointestinal hormones regulating appetite. Philos Trans R Soc Lond B Biol Sci 2006; 361: 1187-1209.

26 Kastin AJ, Akerstrom V, Pan W. Interactions of glucagon-like peptide-1 (GLP-1) with the blood-brain barrier. J Mol Neurosci 2002; 18: 7-14.

27 Vrang N, Larsen PJ. Preproglucagon derived peptides GLP-1, GLP-2 and oxyntomodulin in the CNS: role of peripherally secreted and centrally produced peptides. Prog Neurobiol 2010; 92: 442-462.

28 Vrang N, Phifer CB, Corkern MM, Berthoud HR. Gastric distension induces C-Fos in medullary GLP-1/2-containing neurons. Am J Physiol Regul Integr Comp Physiol 2003; 285: R470-R478

29 Rinaman L. Interoceptive stress activates glucagon-like peptide- 1 neurons that project to the hypothalamus. Am J Physiol 1999; 277(Pt 2): R582-R590.

30 Rinaman L. A functional role for central glucagon-like peptide-1 receptors in lithium chloride-induced anorexia. Am J Physiol 1999; 277(Pt 2): R1537-R1540.

31 Lachey JL, D'Alessio DA, Rinaman L, Elmquist JK, Drucker DJ, Seeley RJ. The role of central GLP-1 in mediating the effects of visceral illness: Differential effects in rats and mice. Endocrinology 2005; 146: 458-462.

32 Barrera JG, Jones KR, Herman JP, D'Alessio DA, Woods SC, Seeley RJ. Hyperphagia and increased fat accumulation in two models of chronic CNS glucagonlike peptide-1 loss of function. J Neurosci 2011; 31: 3904-3913.

33 Kanoski SE, Fortin SM, Arnold M, Grill HJ, Hayes MR. Peripheral and central GLP-1 receptor populations mediate the anorectic effects of peripherally administered GLP-1 receptor agonists, liraglutide and exendin-4. Endocrinology 2011; 152: 3103-3112.

34 Hisadome K, Reimann F, Gribble FM, Trapp S. Leptin directly depolarizes preproglucagon neurons in the nucleus tractus solitarius: electrical properties of glucagon-like Peptide 1 neurons. Diabetes 2010; 59: 1890-1898.

35 Holmes GM, Browning KN, Tong M, Qualls-Creekmore E, Travagli RA. Vagally mediated effects of glucagon-like peptide 1 : in vitro and in vivo gastric actions. $J$ Physiol 2009; 587(Pt 19): 4749-4759.

36 Flint A, Raben A, Astrup A, Holst JJ. Glucagon-like Peptide 1 Promotes Satiety and Suppresses Energy Intake in Humans. J Clin Invest 1998; 101: 515-520.

37 Gutzwiller JP, ke B, Drewe J, Hildebrand P, Ketterer S, Handschin D et al. Glucagon-like peptide-1: a potent regulator of food intake in humans. Gut 1999; 44: 81-86.

38 Gutzwiller JP, Drewe J, Goke B, Schmidt H, Rohrer B, Lareida J et al. Glucagon-like peptide-1 promotes satiety and reduces food intake in patients with diabetes mellitus type 2. Am J Physiol 1999; 276(Pt 2): R1541-R1544.

39 Verdich C, Flint A, Gutzwiller JP, Naslund E, Beglinger C, Hellstrom PM et al. A meta-analysis of the effect of glucagon-like peptide-1 (7-36) amide on ad libitum energy intake in humans. J Clin Endocrinol Metab 2001; 86: 4382-4389.
40 Astrup A, Carraro R, Finer N, Harper A, Kunesova M, Lean ME et al. Safety, tolerability and sustained weight loss over 2 years with the once-daily human GLP-1 analog, liraglutide. Int J Obes (Lond) 2012; 36: 843-854.

41 Williams DL, Baskin DG, Schwartz MW. Evidence that intestinal glucagonlike peptide-1 plays a physiological role in satiety. Endocrinology 2009; 150: 1680-1687.

42 Patterson JT, Ottaway N, Gelfanov VM, Smiley DL, Perez-Tilve D, Pfluger PT et al. A novel human-based receptor antagonist of sustained action reveals body weight control by endogenous GLP-1. ACS Chem Biol 2011; 6: 135-145.

43 Le Roux CW, Welbourn R, Werling M, Osborne A, Kokkinos A, Laurenius A et al. Gut hormones as mediators of appetite and weight loss after Roux-en-Y gastric bypass. Ann Surg 2007; 246: 780-785.

44 Bowen J, Noakes M, Clifton PM. Appetite regulatory hormone responses to various dietary proteins differ by body mass index status despite similar reductions in ad libitum energy intake. J Clin Endocrinol Metab 2006; 91: 2913-2919.

45 Lodefalk M, Carlsson-Skwirut C, Holst JJ, Aman J, Bang P. Effects of fat supplementation on postprandial GIP, GLP-1, ghrelin and IGFBP-1 levels: a pilot study on adolescents with type 1 diabetes. Horm Res Paediatr 2010; 73: 355-362.

46 Frost GS, Brynes AE, Dhillo WS, Bloom SR, McBurney MI. The effects of fiber enrichment of pasta and fat content on gastric emptying, GLP-1, glucose, and insulin responses to a meal. Eur J Clin Nutr 2003; 57: 293-298.

47 Vilsboll T, Krarup T, Sonne J, Madsbad S, Volund A, Juul AG et al. Incretin secretion in relation to meal size and body weight in healthy subjects and people with type 1 and type 2 diabetes mellitus. J Clin Endocrinol Metab 2003 88: 2706-2713.

48 Holst JJ, Schwartz TW, Lovgreen NA, Pedersen O, Beck-Nielsen H. Diurnal profile of pancreatic polypeptide, pancreatic glucagon, gut glucagon and insulin in human morbid obesity. Int J Obes 1983; 7: 529-538.

49 Verdich C, Toubro S, Buemann B, Lysgard MJ, Juul HJ, Astrup A. The role of postprandial releases of insulin and incretin hormones in meal-induced satietyeffect of obesity and weight reduction. Int J Obes 2001; 25: 1206-1214.

50 Tomasik P, Sztefko K, Starzyk J. Entero-insular axis in children with simple obesity. Pediatr Endocrinol Diabetes Metab 2009; 15: 63-69.

51 Chanoine JP, Mackelvie KJ, Barr SI, Wong AC, Meneilly GS, Elahi DH. GLP-1 and appetite responses to a meal in lean and overweight adolescents following exercise. Obesity (Silver Spring) 2008; 16: 202-204.

52 Carr RD, Larsen MO, Jelic K, Lindgren O, Vikman J, Holst JJ et al. Secretion and dipeptidyl peptidase-4-mediated metabolism of incretin hormones after a mixed meal or glucose ingestion in obese compared to lean, nondiabetic men. J Clin Endocrinol Metab 2010; 95: 872-878.

53 Toft-Nielsen MB, Damholt MB, Madsbad S, Hilsted LM, Hughes TE, Michelsen BK et al. Determinants of the impaired secretion of glucagon-like peptide-1 in type 2 diabetic patients. J Clin Endocrinol Metab 2001; 86: 3717-3723.

54 Muscelli E, Mari A, Casolaro A, Camastra S, Seghieri G, Gastaldelli A et al. Separate impact of obesity and glucose tolerance on the incretin effect in normal subjects and type 2 diabetic patients. Diabetes 2008; 57: 1340-1348.

55 Naslund E, Gryback P, Backman L, Jacobsson H, Holst JJ, Theodorsson E et al. Distal small bowel hormones: correlation with fasting antroduodenal motility and gastric emptying. Dig Dis Sci 1998; 43: 945-952.

56 Rask E, Olsson T, Soderberg S, Johnson O, Seckl J, Holst JJ et al. Impaired incretin response after a mixed meal is associated with insulin resistance in nondiabetic men. Diabetes Care 2001; 24: 1640-1645.

57 Aoki K, Miyazaki T, Nagakura J, Orime K, Togashi Y, Terauchi Y. Effects of premeal versus post-meal administration of miglitol on plasma glucagon-like peptide-1 and glucosedependent insulinotropic polypeptide levels in healthy men. Endocr J 2010; 57: 673-677.

58 Diakogiannaki E, Gribble FM, Reimann F. Nutrient detection by incretin hormone secreting cells. Physiol Behav 2012; 106: 387-393.

59 Ahren B, Holst JJ. The cephalic insulin response to meal ingestion in humans is dependent on both cholinergic and noncholinergic mechanisms and is important for postprandial glycemia. Diabetes 2001; 50: 1030-1038.

60 Ueda SY, Yoshikawa T, Katsura Y, Usui T, Fujimoto S. Comparable effects of moderate intensity exercise on changes in anorectic gut hormone levels and energy intake to high intensity exercise. J Endocrinol 2009; 203: 357-364.

61 Korner J, Bessler M, Inabnet W, Taveras C, Holst JJ. Exaggerated glucagon-like peptide- 1 and blunted glucose-dependent insulinotropic peptide secretion are associated with Roux-en-Y gastric bypass but not adjustable gastric banding. Surg Obes Relat Dis 2007; 3: 597-601.

62 le Roux CW, Welbourn R, Werling M, Osborne A, Kokkinos A, Laurenius A et al. Gut hormones as mediators of appetite and weight loss after Roux-en-Y gastric bypass. Ann Surg 2007; 246: 780-785.

63 Morinigo R, Moize V, Musri M, Lacy AM, Navarro S, Marin JL et al. Glucagon-like peptide-1, peptide $Y Y$, hunger, and satiety after gastric bypass surgery in morbidly obese subjects. J Clin Endocrinol Metab 2006; 91: 1735-1740. 
64 Naslund E, Backman L, Holst JJ, Theodorsson E, Hellstrom PM. Importance of small bowel peptides for the improved glucose metabolism 20 years after jejunoileal bypass for obesity. Obes Surg 1998; 8: 253-260.

65 Falken Y, Hellstrom PM, Holst JJ, Naslund E. Changes in glucose homeostasis after Roux-en-Y gastric bypass surgery for obesity at day three, two months, and one year after surgery: role of gut peptides. J Clin Endocrinol Metab 2011; 96: 2227-2235.

66 Alam ML, Van der Schueren BJ, Ahren B, Wang GC, Swerdlow NJ, Arias S et al. Gastric bypass surgery, but not caloric restriction, decreases dipeptidyl peptidase- 4 activity in obese patients with type 2 diabetes. Diabetes Obes Metab 2011; 13: 378-381.

67 Lim GE, Huang GJ, Flora N, LeRoith D, Rhodes CJ, Brubaker PL. Insulin regulates glucagon-like peptide-1 secretion from the enteroendocrine $L$ cell. Endocrinology 2009; 150: 580-591.

68 Pournaras DJ, Osborne A, Hawkins SC, Vincent RP, Mahon D, Ewings P et al. Remission of type 2 diabetes after gastric bypass and banding: mechanisms and 2 year outcomes. Ann Surg 2010; 252: 966-971.

69 Knop FK. Resolution of type 2 diabetes following gastric bypass surgery: involvement of gut-derived glucagon and glucagonotropic signalling? Diabetologia 2009; 52: 2270-2276.

70 Scheen AJ, De FJ, De RA, Paquot N. Bariatric surgery in patients with type 2 diabetes: benefits, risks, indications and perspectives. Diabetes Metab 2009; 35(Pt 2): 537-543.

71 Dirksen C, Hansen DL, Madsbad S, Hvolris LE, Naver LS, Holst JJ et al. Postprandial diabetic glucose tolerance is normalized by gastric bypass feeding as opposed to gastric feeding and is associated with exaggerated GLP-1 secretion: a case report. Diabetes Care 2010; 33: 375-377.

72 Salehi M, Prigeon RL, D'Alessio DA. Gastric bypass surgery enhances glucagonlike peptide 1-stimulated postprandial insulin secretion in humans. Diabetes 2011; 60: 2308-2314.

73 Hansen L, Deacon CF, Orskov C, Holst JJ. Glucagon-like peptide-1-(7-36)amide is transformed to glucagon-like peptide-1-(9-36)amide by dipeptidyl peptidase IV in the capillaries supplying the $L$ cells of the porcine intestine [In Process Citation]. Endocrinology 1999; 140: 5356-5363.

74 Deacon CF, Pridal L, Klarskov L, Olesen M, Holst JJ. Glucagon-like peptide 1 undergoes differential tissue-specific metabolism in the anesthetized pig. Am J Physiol 1996; 271(Pt 1): E458-E464.

75 Wettergren A, Pridal L, Wojdemann M, Holst JJ. Amidated and nonamidated glucagon-like peptide-1 (GLP-1): non-pancreatic effects (cephalic phase acid secretion) and stability in plasma in humans. Regul Pept 1998; 77: 83-87.

76 Vilsboll T, Krarup T, Deacon CF, Madsbad S, Holst JJ. Reduced postprandial concentrations of intact biologically active glucagon-like peptide 1 in type 2 diabetic patients. Diabetes 2001; 50: 609-613.

77 Mari A, Sallas WM, He YL, Watson C, Ligueros-Saylan M, Dunning BE et al. Vildagliptin, a Dipeptidyl Peptidase-IV Inhibitor, Improves Model-Assessed \{beta\}-Cell Function in Patients with Type 2 Diabetes. J Clin Endocrinol Metab 2005; 90: 4888-4894.

78 Deacon CF, Carr RD, Holst JJ. DPP-4 inhibitor therapy: new directions in the treatment of type 2 diabetes. Front Biosci 2008; 13: 1780-1794.

79 Williams DL. Minireview: finding the sweet spot: peripheral versus central glucagon-like peptide 1 action in feeding and glucose homeostasis. Endocrinology 2009; 150: 2997-3001.

80 Holst JJ, Deacon CF. Glucagon-like peptide-1 mediates the therapeutic actions of DPP-IV inhibitors. Diabetologia 2005; 48: 612-615.

81 Vahl TP, Tauchi M, Durler TS, Elfers EE, Fernandes TM, Bitner RD et al. Glucagonlike peptide-1 (GLP-1) receptors expressed on nerve terminals in the portal vein mediate the effects of endogenous GLP-1 on glucose tolerance in rats. Endocrinology 2007; 148: 4965-4973.

82 Nakagawa A, Satake H, Nakabayashi H, Nishizawa M, Furuya K, Nakano S et al. Receptor gene expression of glucagon-like peptide-1, but not glucose-dependent insulinotropic polypeptide, in rat nodose ganglion cells. Auton Neurosci 2004; 110: 36-43.

83 Bucinskaite V, Tolessa T, Pedersen J, Rydqvist B, Zerihun L, Holst JJ et al. Receptor-mediated activation of gastric vagal afferents by glucagon-like peptide-1 in the rat. Neurogastroenterol Motil 2009; 21: 978-e78.

84 Baumgartner I, Pacheco-Lopez G, Ruttimann EB, Arnold M, Asarian L, Langhans $W$ et al. Hepatic-portal vein infusions of glucagon-like peptide-1 reduce meal size and increase c-Fos expression in the nucleus tractus solitarii, area postrema and central nucleus of the amygdala in rats. J Neuroendocrinol 2010; 22: $557-563$.

85 Grill HJ, Hayes MR. The nucleus tractus solitarius: a portal for visceral afferent signal processing, energy status assessment and integration of their combined effects on food intake. Int J Obes (Lond) 2009; 33(Suppl 1): S11-S15.
86 Sandoval DA, Bagnol D, Woods SC, D'Alessio DA, Seeley RJ. Arcuate glucagonlike peptide 1 receptors regulate glucose homeostasis but not food intake. Diabetes 2008; 57: 2046-2054.

87 Nakabayashi H, Nishizawa M, Nakagawa A, Takeda R, Niijima A. Vagal hepatopancreatic reflex effect evoked by intraportal appearance of tGLP-1. Am J Physiol 1996; 271 (Pt 1): E808-E813.

88 Abbott CR, Monteiro M, Small CJ, Sajedi A, Smith KL, Parkinson JR et al. The inhibitory effects of peripheral administration of peptide $Y Y(3-36)$ and glucagonlike peptide- 1 on food intake are attenuated by ablation of the vagal-brainstemhypothalamic pathway. Brain Res 2005; 1044: 127-131.

89 Ruttimann EB, Arnold M, Hillebrand JJ, Geary N, Langhans W. Intrameal hepatic portal and intraperitoneal infusions of glucagon-like peptide-1 reduce spontaneous meal size in the rat via different mechanisms. Endocrinology 2009; 150: 1174-1181.

90 Hayes MR, Kanoski SE, De Jonghe BC, Leichner TM, Alhadeff AL, Fortin SM et al. The common hepatic branch of the vagus is not required to mediate the glycemic and food intake suppressive effects of glucagon-like-peptide-1. Am J Physiol Regul Integr Comp Physiol 2011; 301: R1479-R1485.

91 Imeryuz N, Yegen BC, Bozkurt A, Coskun T, Villanueva-Penacarrillo ML, Ulusoy NB. Glucagon-like peptide-1 inhibits gastric emptying via vagal afferent- mediated central mechanisms. Am J Physiol 1997; 273(Pt 1): G920-G927.

92 Wettergren A, Wojdemann M, Holst JJ. Glucagon-like peptide-1 inhibits gastropancreatic function by inhibiting central parasympathetic outflow. Am J Physiol 1998; 275(Pt 1): G984-G992.

93 Wettergren A, Petersen H, Orskov C, Christiansen J, Sheikh SP, Holst JJ. Glucagon-like peptide-1 7-36 amide and peptide $Y Y$ from the L-cell of the ileal mucosa are potent inhibitors of vagally induced gastric acid secretion in man. Scand J Gastroenterol 1994; 29: 501-505.

94 Wettergren A, Wojdemann M, Meisner S, Stadil F, Holst JJ. The inhibitory effect of glucagon-like peptide-1 (GLP-1) 7-36 amide on gastric acid secretion in humans depends on an intact vagal innervation. Gut 1997; 40: 597-601.

95 Pannacciulli N, Le DS, Salbe AD, Chen K, Reiman EM, Tataranni PA et al. Postprandial glucagon-like peptide-1 (GLP-1) response is positively associated with changes in neuronal activity of brain areas implicated in satiety and food intake regulation in humans. Neuroimage 2007; 35: 511-517.

96 van Dijk G, Thiele TE. Glucagon-like peptide-1 (7-36) amide: a central regulator of satiety and interoceptive stress. Neuropeptides 1999; 33: 406-414.

97 Orskov C, Poulsen SS, Moller M, Holst JJ. Glucagon-like peptide I receptors in the subfornical organ and the area postrema are accessible to circulating glucagonlike peptide I. Diabetes 1996; 45: 832-835.

98 Baraboi ED, Smith P, Ferguson AV, Richard D. Lesions of area postrema and subfornical organ alter exendin-4-induced brain activation without preventing the hypophagic effect of the GLP-1 receptor agonist. Am J Physiol Regul Integr Comp Physiol 2010; 298: R1098-R1110.

99 Plamboeck A, Veedfald S, Deacon C, Wettergren A, Svendsen L, Meisner S et al. The effect of GLP-1 on fod intake is lost in Truncal vagotomized subjects. Diabetes 2012; 61(Suppl 1): A475.

100 Suzuki K, Simpson KA, Minnion JS, Shillito JC, Bloom SR. The role of gut hormones and the hypothalamus in appetite regulation. Endocr $J$ 2010; 57: 359-372.

101 Rinaman L. Interoceptive stress activates glucagon-like peptide-1 neurons that project to the hypothalamus. Am J Physiol 1999; 277(Pt 2): R582-R590.

102 Raun K, Jelsing J, Vrang N, Tang-Christensen M, Dahl K, Knudsen LB. The GLP-1 analog liraglutide activates brainstem and hypothalamic neurons involved in appetite regulation. Diabetes 2010; 59(Suppl 1): A159-A160.

103 Tesauro M, Schinzari F, Caramanti M, Lauro R, Cardillo C. Cardiovascular and metabolic effects of ghrelin. Curr Diabetes Rev 2010; 6: 228-235.

104 Rogers RC, Hermann GE. Mechanisms of action of CCK to activate central vagal afferent terminals. Peptides 2008; 29: 1716-1725.

105 Riediger T, Eisele N, Scheel C, Lutz TA. Effects of glucagon-like peptide 1 and oxyntomodulin on neuronal activity of ghrelin-sensitive neurons in the hypothalamic arcuate nucleus. Am J Physiol Regul Integr Comp Physiol 2010; 298: R1061-R1067.

106 Nauck MA. Unraveling the science of incretin biology. Am J Med 2009; 122(Suppl): S3-S10.

107 McGill JB. Impact of incretin therapy on islet dysfunction: an underlying defect in the pathophysiology of type 2 diabetes. Postgrad Med 2009; 121: 46-58.

108 Agerso H, Jensen LB, Elbrond B, Rolan P, Zdravkovic M. The pharmacokinetics, pharmacodynamics, safety and tolerability of NN2211, a new long-acting GLP-1 derivative, in healthy men. Diabetologia 2002; 45: 195-202.

109 Kim D, Macconell L, Zhuang D, Kothare PA, Trautmann M, Fineman M et al. Effects of once-weekly dosing of a long-acting release formulation of exenatide on glucose control and body weight in subjects with type 2 diabetes. Diabetes Care 2007; 30: 1487-1493. 
110 Monami M, Marchionni N, Mannucci E. Glucagon-like peptide-1 receptor agonists in type 2 diabetes: a meta-analysis of randomized clinical trials. Eur $J$ Endocrinol 2009; 160: 909-917.

111 Norris SL, Lee N, Thakurta S, Chan BKS. Exenatide efficacy and safety: a systematic review. Diabet Med 2009; 26: 837-846.

112 Jendle J, Nauck MA, Matthews DR, Frid A, Hermansen K, During M et al. Weight loss with liraglutide, a once-daily human glucagon-like peptide- 1 analogue for type 2 diabetes treatment as monotherapy or added to metformin, is primarily as a result of a reduction in fat tissue. Diabetes Obes Metab 2009; 11: 1163-1172.

113 Nauck M, Marre M. Adding liraglutide to oral antidiabetic drug monotherapy: efficacy and weight benefits. Postgrad Med 2009; 121: 5-15.

114 Vilsboll T, Zdravkovic M, Le-Thi T, Krarup T, Schmitz O, Courreges JP et al. Liraglutide, a long-acting human GLP-1 analog, given as monotherapy significantly improves glycemic control and lowers body weight without risk of hypoglycemia in patients with type 2 diabetes mellitus. Diabetes Care 2007; 30: 1608-1610.

115 Nauck M, Frid A, Hermansen K, Shah NS, Tankova T, Mitha IH et al. Efficacy and safety comparison of liraglutide, glimepiride, and placebo, all in combination with metformin, in type 2 diabetes: the LEAD (Liraglutide Effect and Action in Diabetes)-2 study. Diabetes Care 2009; 32: 84-90.

116 Buse JB, Rosenstock J, Sesti G, Schmidt WE, Montanya E, Brett JH et al. Liraglutide once a day versus exenatide twice a day for type 2 diabetes: a 26-week randomised, parallel-group, multinational, open-label trial (LEAD-6). Lancet 2009; 374: 39-47.

117 Inoue K, Maeda N, Kashine S, Fujishima Y, Kozawa J, Hiuge-Shimizu A et al. Short-term effects of liraglutide on visceral fat adiposity, appetite, and food preference: a pilot study of obese Japanese patients with type 2 diabetes. Cardiovasc Diabetol 2011; 10: 109.

118 Astrup A, Rossner S, Van Gaal L, Rissanen A, Niskanen L, Al Hakim M et al. Effects of liraglutide in the treatment of obesity: a randomised, double-blind, placebocontrolled study. Lancet 2009; 374: 1606-1616.

119 Kelly AS, Metzig AM, Rudser KD, Fitch AK, Fox CK, Nathan BM et al. Exenatide as a weight-loss therapy in extreme pediatric obesity: a randomized, controlled pilot study. Obesity 2012; 20: 364-370.

120 Rosenstock J, Klaff LJ, Schwartz S, Northrup J, Holcombe JH, Wilhelm K et al. Effects of exenatide and lifestyle modification on body weight and glucose tolerance in obese subjects with and without prediabetes. Diabetes Care 2010; 33: $1173-1175$

121 Pinelli NR, Jantz A, Smith Z, Abouhassan A, Ayar C, Jaber NA et al. Effect of administration time of exenatide on satiety responses, blood glucose, and adverse events in healthy volunteers. J Clin Pharmacol 2011; 51: 165-172.
122 Horowitz M, Flint A, Doran S, Rasmussen MF, Kapitza C, Andreasen AH et al Effects of the once-daily human GLP-1 analogue liraglutide on appetite and energy intake in type 2 diabetes. Diabetologia 2008; 51(Suppl 1): S355.

123 Linnebjerg H, Park S, Kothare PA, Trautmann ME, Mace K, Fineman M et al. Effect of exenatide on gastric emptying and relationship to postprandial glycemia in type 2 diabetes. Regul Pept 2008; 151: 123-129.

124 Juhl CB, Hollingdal M, Sturis J, Jakobsen G, Agerso H, Veldhuis J et al. Bedtime administration of NN2211, a long-acting GLP-1 derivative, substantially reduces fasting and postprandial glycemia in type 2 diabetes. Diabetes 2002; 51 424-429.

125 Jelsing J, Vrang N, Hansen G, Ravn K, Tang-Christensen M, Knudsen LB. Liraglutide: Short lived effect on gastric emptying - long lasting effects on bodyweight. Diabetes Obes Metab 2012; 14: 531-538.

126 Imeryuz N, Yegen BC, Bozkurt A, Coskun T, Villanueva-Penacarrillo ML, Ulusoy NB. Glucagon-like peptide-1 inhibits gastric emptying via vagal afferent-mediated central mechanisms. Am J Physiol 1997; 273(Pt 1): G920-G927.

127 Buse JB, Henry RR, Han J, Kim DD, Fineman MS, Baron AD. Effects of exenatide (exendin-4) on glycemic control over 30 weeks in sulfonylurea-treated patients with type 2 diabetes. Diabetes Care 2004; 27: 2628-2635.

128 DeFronzo RA, Ratner RE, Han J, Kim DD, Fineman MS, Baron AD. Effects of exenatide (exendin-4) on glycemic control and weight over 30 weeks in metformin-treated patients with type 2 diabetes. Diabetes Care 2005; 28: 1092-1100.

129 Garber A, Henry RR, Ratner R, Hale P, Chang CT, Bode B. Liraglutide, a once-daily human GLP-1 analogue, provides sustained improvements in glycaemic control and weight for two years as monotherapy compared with glimepiride in patients with type 2 diabetes. Diabetes Obes Metab 2010; 13: 348-356.

130 Russell-Jones D, Vaag A, Schmitz O, Sethi BK, Lalic N, Antic S et al. Liraglutide vs insulin glargine and placebo in combination with metformin and sulfonylurea therapy in type 2 diabetes mellitus: a randomised controlled trial (LEAD-5 met + SU). Diabetologia 2009; 52: 2046-2055.

131 Zinman B, Hoogwerf BJ, Duran GS, Milton DR, Giaconia JM, Kim DD et al. The effect of adding exenatide to a thiazolidinedione in suboptimally controlled type 2 diabetes: a randomized trial. Ann Intern Med 2007; 146: 477-485.

132 Blonde L, Russell-Jones D. The safety and efficacy of liraglutide with or without oral antidiabetic drug therapy in type 2 diabetes: an overview of the LEAD 1-5 studies. Diabetes Obes Metab 2009; 11(Suppl 3): 26-34.

(c) This work is licensed under a Creative Commons AttributionMMERIEHIS RESERVED NonCommercial-NoDerivs 3.0 Unported License. To view a copy of this license, visit http://creativecommons.org/licenses/by-nc-nd/3.0/ 